\title{
Case Based Reasoning Method untuk Sistem Pakar Diagnosa Penyakit Sapi
}

\author{
Irvan Muzakkir ${ }^{\mathrm{a}, 1}$ dan Marniyati Husain Botutihe ${ }^{\mathrm{a}, 2, *}$ \\ ${ }^{a}$ Universitas Ichsan Gorontalo, Jln. Achmad Najamuddin, Kota Gorontalo dan Kode Pos 96115, Indonesia \\ ${ }^{1}$ irvanmuzakkir32@gmail.com; ${ }^{2}$ marniyati.h.botutihe@gmail.com \\ * corresponding author
}

\section{Kata Kunci: \\ CBR \\ Scours \\ Pink Eye \\ Penyakit Sapi \\ Peternak}

INFORMASI ARTIKEL

Dikirim: 14 Januari 2020

Diulas: 12 Februari 2020

Direvisi: 11 April 2020

Diterbitkan: 27 April 2020

\section{Keywords: \\ CBR \\ Scours \\ Pink Eye \\ Cattle Disease \\ Farmers}

\section{ABSTRAK}

Penelitian ini membahas tentang Penerapan Metode Case Based Reasoning (CBR) untuk Sistem Pakar Diagnosa Penyakit Ternak Sapi. Diawali dengan pengumpulan data dengan melakukan konsultasi kepada pakar yang berada pada Dinas Pertanian Bidang Kesehatan Hewan Kabupaten Pohuwato. Data yang diperoleh berupa data nama penyakit dan data gejala. Data tersebut dioleh berdasarkan langkah-langkah perhitungan metode CBR sehingga diperoleh hasil diagnosa dan solusi yang diberikan untuk penanganan penyakit. Peneliti telah melakukan analisa dan membuat listing program untuk membangun sebuah system yang nantinya akan digunakan oleh para peternak. Berdasarkan perhitungan CBR kasus Scours yang memiliki bobot paling rendah yaitu 0,09 sedangkan bobot yang paling tinggi dimiliki oleh kasus Pink Eye yaitu 1. Dalam proses ini memberikan solusi dengan kemiripan bobot dari kasus lama dengan kasus baru yang lebih tinggi. Pada kasus Pink Eye memiliki bobot lebih tinggi dan positif, solusi yang diberikan adalah pemberian anti alergi, anti biotik dan vitamin. Berdasarkan hasil yang diperoleh dapat ditarik kesimpulan bahwa penerapan metode CBR baik digunakan untuk diagnosa penyakit ternak sapi yang sangat membantu peternak dalam menangani penyakit ternak sapi.

\section{ABSTRACT}

This study discusses about the Application of Case Based Reasoning (CBR) Method for Expert Systems in Diagnosing Cattle Disease. Beginning with data collection by consulting experts in the Department of Agriculture in Animal Health, Pohuwato Regency. The data obtained in the form of data names of disease and symptom data. The data is obtained based on the steps of the CBR method calculation in order to obtain the results of the diagnosis and the solution provided for handling the disease. Researcher have analyzed and create program listings to build a system that will be used by farmers. Based on CBR calculations Scours case which has the lowest weight is 0.09 while the highest weight is owned by the Pink Eye case 1 . In this process provides a solution to the similarity of the case weight from the old case to the new higher case. In the case of Pink Eye having a higher weight and positive exposure to pink eye disease, the solution given is the provision of anti-allergic, anti-biotic and vitamin Based on the results obtained, it can be concluded that the application of the CBR method is good for using cattle disease and is very helpful for farmers in dealing with cattle disease.

This is an open access article under the $\mathrm{CC}-\mathrm{BY}-\mathrm{SA}$ license.

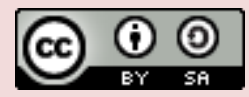

\section{Pendahuluan}

Indonesia khususnya Provinsi Gorontalo mempunyai potensi peternakan yang cukup besar dengan produk unggulannya yaitu hewan ternak sapi, produk unggulan peternakan tersebut berkembang dan terfokus dalam kawasan pengembangan pusat produksi. Dari berbagai macam jenis hewan ternak yang banyak dipelihara oleh peternak di pedesaan adalah sapi. Sapi menduduki peringkat pertama sebagai komoditas unggulan, diikuti oleh ayam dan kambing[1]. Salah satu program pemerintah untuk mensejahterakan rakyat adalah melalui program bantuan ternak sapi. Sapi juga merupakan hewan ternak terbesar populasinya di Kabupaten Pohuwato Provinsi Gorontalo [2]. Hal ini dibuktikan dengan perkembangan jumlah ternak sapi dari 
tahun ketahun yang semakin meningkat yang diperoleh berdasarkan data 3 tahun terakhir dari jumlah 28.265 ekor ternak sapi mencapai 34.136 ekor ternak sapi ditahun 2018.

Tujuan dari penelitian ini adalah untuk memberikan hasil diagnosa dalam membantu masyarakat khususnya para peternak dalam menganalisa gejala-gejala penyakit yang diderita oleh sapi, sehingga mereka dapat mengetahui dan memutuskan, apakah penyakit yang diderita sapi harus segera ditindaki dengan serius atau menjalani perawatan. selain itu juga memberikan kemudahan kepada pihak Dinas Pertanian Bidang Kesehatan Hewan Kabupaten Pohuwato dalam menangani permasalahan-permasalahan penyakit pada sapi sehingga populasi sapi di Kabupaten Pohuwato terus bertambah. Membangun sistem pakar berbasis web untuk mendiagnosa penyakit yang sering diderita sapi dengan menggunakan bahasa pemrograman PHP dan aplikasi Dreamweaver dan penerapan metode Case Based Reasoning berdasarkan perhitungan cyclomatic complexity.

Identifikasi masalah pada penelitian ini adalah tingginya populasi sapi di Kabupaten Pohuwato dan kurangnya pemahaman masyarakat dalam menangani penyakit pada sapi. Metode Case Based Reasoning (CBR) merupakan salah satu metode yang mampu melakukan penalaran atau memecahkan permasalahan berdasarkan kasus yang telah ada sebagai solusi masalah baru. Pada metode ini, komputer tidak langsung melakukan penalaran melainkan dari contoh-contoh kasus sebelumnya atau dengan pengalaman para ahli. Metode ini tergolong metode yang cepat dalam melakukan proses belajar (learning). Hal ini dikarenakan solusi untuk suatu masalah sudah tersimpan di dalam casebase [3].

\section{Metode}

Pada penelitian ini diawali dengan tahap pertama yaitu pengambilan sampel data gejala penyakit dan data pendukung lainnya dari Dinas Pertanian Bidang Kesehatan Hewan Kabupaten Pohuwato. Data awal berupa data gejala penyakit, data penyebab penyakit, data solusi/penanganan, dan data basis aturan. Tahap kedua, dilakukan analisa dan pembuatan listing program. Tahap ketiga yaitu menyusun laporan hasil penelitian. Sistem dibangun dengan menggunakan PHP, MySql dan Adobe Dreamweaver. Setelah sistem selesai dibangun dilakukan pengujian dengan menggunakan White Box dan Black Box.

Sistem pakar adalah sistem komputer yang ditujukan untuk meniru semua aspek, kemampuan pengambilan keputusan seorang pakar [4]. Case Based Reasoning adalah metode utama yang diterapkan pada mesin inferensi Sistem Konseling Interaktif ini. Secara garis besar, konsep dari Case Based Reasoning adalah menyelesaikan suatu masalah berdasarkan pengalaman memecahkan masalah/kasus yang mirip di masa lalu [5]. Ada 4 siklus yang dilalui dalam metode Case Based Reasoning, yaitu:

1. Mencari kasus-kasus yang mirip (Retrieve)

2. Menggunakan informasi dari kasus yang mirip untuk memprediksi solusi yang tepat (Reuse)

3. Merevisi solusi yang diberikan (Revise)

4. Menyimpan hasil penanganan kasus agar dapat digunakan untuk pembelajaran selanjutnya (Retain) [6].

Pada siklus retrieve dilakukan pencarian kesamaan (similarity) antara kasus yang sedang ditangani (new case) dengan kasus-kasus yang tersimpan didalam basis pengetahuan. Kasus-kasus tersimpan yang paling mirip dengan new case akan dijadikan patokan sebagai retrieved case. Selanjutnya pada siklus reuse, solusi yang pernah diterapkan pada retrieved case dijadikan sebagai prediksi solusi atau solusi yang diusulkan (suggested solution) bagi kasus yang sedang ditangani. Solusi tersebut dicobakan sebagai solusi untuk selanjutnya dikonfirmasi ketepatan calon solusi itu untuk menjadi solusi yang tepat bagi new case. Pada siklus revise, konfirmasi revisi tentang calon solusi yang diusulkan akan dijadikan patokan untuk dipelajari.

Pada siklus ini akan dilakukan pembelajaran (learning) agar pada sesi berikutnya sistem dapat memberikan solusi yang tepat bagi kasus yang sama. Jika konfirmasi yang diterima adalah tepat, maka calon solusi tersebut akan diresmikan menjadi solusi yang tepat bagi masalah yang sedang ditangani. Setelah dipastikan mendapatkan solusi yang tepat, pada siklus retain selanjutnya kasus tersebut disimpan untuk referensi bagi kasus yang mirip yang ditemukan pada sesi selanjutnya. Menurut beberapa artikel yang membahas Case Based Reasoning, metode ini tergolong metode yang cepat dalam melakukan proses belajar (learning). Hal ini dikarenakan solusi untuk suatu masalah sudah tersimpan di dalam casebase.

Permasalahan yang terjadi yaitu sapi mudah terjangkit beberapa penyakit. Para peternak khususnya pedesaan terkadang sulit menemukan tenaga yang ahli/pakar terhadap penyakit hewan ternak. Salah satu bagian yang paling penting dalam penanganan kesehatan ternak adalah melakukan pengamatan terhadap ternak yang sakit melalui pemeriksaan ternak yang diduga sakit. Pemeriksaan ternak yang diduga sakit merupakan suatu proses untuk menentukan dan mengamati perubahan yang terjadi pada ternak melalui gejalagejala yang nampak sehingga dapat diambil kesimpulan berdasarkan permasalahan tersebut, maka diperlukan suatu metode yang mampu membatu dalam mendiagnosa penyakit ternak sapi karena penyakit pada sapi masih relatif sedikit yang diketahui oleh masyarakat. 


\section{Hasil dan Pembahasan}

\section{A. Pengumpulan Data}

Dalam penelitian ini dilakukan pengumpulan data di Dinas Pertanian Bidang Kesehatan Hewan Kabupaten Pohuwato yang berlokasi di Kecamatan Marisa Kabupaten Pohuwato. Data yang diperoleh langsung dari pakar/sumbernya yaitu satu orang dokter spesialis kesehatan hewan. Diharapkan dengan adanya perubahan dalam penelitian ini mampu memiliki manfaat bagi banyak orang. Data penyakit dan data gejala penyakit diuraikan pada Tabel 1.

Tabel 1. Daftar Nama Penyakit

\begin{tabular}{cl}
\hline Kode Penyakit & \multicolumn{1}{c}{ Nama Penyakit } \\
\hline P01 & BEF (Bovire Epimeral Fever) \\
\hline P02 & Pink Eye \\
\hline P03 & SCOURS (Diare Ganas) \\
\hline P04 & Bloat \\
\hline P05 & Peradangan Pada Puting (Mastitis) \\
\hline P06 & Helminthiasis (cacing) \\
\hline P07 & Fasciolasis (cacing Hati) \\
\hline P08 & Kaskado \\
\hline P09 & Scabies \\
\hline P10 & Berak Darah Pada Sapi \\
\hline
\end{tabular}

Tabel 1 menunjukkan data penyakit pada sapi yang terdiri dari 10 jenis penyakit. Dalam penelitian hal yang paling utama adalah data awal. Data ini diperoleh langsung dari pakar/sumbernya yaitu satu orang dokter spesialis kesehatan hewan.

Tabel 2. Tabel Gejala Penyakit

\begin{tabular}{|c|c|}
\hline Kode Gejala & Nama Gejala \\
\hline G1 & Nafsu Makan Menurun \\
\hline G2 & Demam Intermiten Selama Masa Inkubasi 3-4 Hari \\
\hline G3 & Kulit Terkelupas \\
\hline G4 & Lemas Dan Mudah Jatuh \\
\hline G5 & Kotoran Konsistensinya Mengeras \\
\hline G6 & Demam \\
\hline G7 & Kelopak Mata Berwarna Merah \\
\hline G8 & Mengalami Kebutaan \\
\hline G9 & Kulit Kusam \\
\hline G10 & Tubuh Gemetaran \\
\hline G11 & Konsistensi Kotoran Cair dan Banyak \\
\hline G12 & Memamabiak Berusaha mengeluarkan Makanan Leawat Mulut \\
\hline G13 & Lambung Penuh Gas \\
\hline G14 & Kotoran Sedikit dan Agak Cair \\
\hline G15 & Lemas dan Kurang Bergairah \\
\hline G16 & Kotoran Bercampur Darah \\
\hline G17 & Peradangan Pada Putting \\
\hline G18 & Produksi Susu Berkurang dan kualitas menurun \\
\hline G19 & Terjadi Infeksi Pada Puting dan Bernanah \\
\hline G20 & Nafsu Makan Bertambah \\
\hline G21 & Berat Badan Menurun dan Kurus \\
\hline G22 & Produksi Air Mata Meningkat/Sapi banyak Mengeluarkan Air Mata \\
\hline G23 & Bulu Berdiri \\
\hline G24 & Terdapat Bunyi Krepitasi pada gambir \\
\hline G25 & Glambir Membengkak \\
\hline G26 & Terdapat Cacing Pada hati \\
\hline G27 & Kulit Rontok \\
\hline G28 & Terdapat Koreng \\
\hline G29 & Luka dan Bercak putih pada bibir dan gusi \\
\hline G30 & Gatal pada salah satu kuku \\
\hline
\end{tabular}

Tabel 2 menunjukkan data jenis gejala-gejala yang sering dialami oleh ternak sapi terdiri dari 30 gejala. Diagnosa penyakit sapi berdasarkan gejala-gejala yang diderita sapi. hasil diagnosa bisa membantu masyarakat khususnya para peternak dalam mengetahui dan memutuskan, apakah penyakit yang diderita sapi harus segera ditindaki dengan serius atau menjalani perawatan.

\section{B. Tampilan Sistem}

Sitem dibangun dengan menggunakan PHP, MySql dan Adobe Dreamweaver. Data yang di masukkan dalam sistem adalah data yang diperoleh dari pakar serta berdasarkan fakta-fakta yang terjadi dilapangan yang sering dikeluhkan oleh para peternak. Beberapa tampilan sistem di uraikan pada Gambar 1. 


\section{Daftar Gejalā}

Tampilkan 10 - bars

\begin{tabular}{|c|c|c|c|c|c|}
\hline No & Kategori Gojala & - Kodo & Nama Gojala & Bobot & + tanbiat \\
\hline 1 & Bakter & 630 & Gatal pada saash sau kuku & 5 & 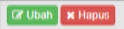 \\
\hline 2 & Battori & 329 & Luka dan Borcak pulith pada bibir dan ousi & 5 & Crobin $\times$ Hapu \\
\hline 3 & Eaxteri & 628 & Terdapat Koreng & 3 & Guain XHapu \\
\hline 4 & Batiteri & 927 & Kull Rontok & 3 & GUath x Hapu \\
\hline 5 & Baxteri & 019 & Terijaci Intoksi Pada Puting dan Bomanah & 5 & Gubah X Hapu \\
\hline 6 & Baxteri & G18 & Produka susu Berkurang dan kuantas menurun & 3 & Crusan $\times$ Hapu \\
\hline 7 & Bateri & Q16 & Kotoran Bercambur Darah & 5 & Trovaih × Xapu \\
\hline 8 & Batteri & 317 & Peradangan Pada Puting & 5 & Govan xHapum \\
\hline 9 & Basteri & 015 & Lemas dan Kurang Bergatiah & 3 & GObaih $\times$ Hapus \\
\hline 10 & Baxter & 614 & Kotoran Sodikt dan Agak Car & 3 & xovoin $\times$ Hapus \\
\hline 11 & Baiteri & 613 & Lambung Penun Gas & 5 & Gubah $\times$ Hapus \\
\hline 12 & Balterl & 812 & Memamabakk Berusaha mengeluarkan Makanan Laavat Mulut & 3 & Gubah $x$ Hapus \\
\hline 3 & Gacing & 625 & Terdapal Cacing Pada hatt & 5 & GUbah $\times$ Hapus \\
\hline 14 & caeing & 625 & Glambir Membengkak & 1 & 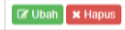 \\
\hline 15 & Cacing & 624 & Terdapal Buryi Krepitasi pada aambir & 3 & Gubah $x$ Hapus \\
\hline 16 & Cacing & 823 & Bulu Berditi & 5 & Gusan $x$ Hapus \\
\hline 17 & Cacing & 622 & 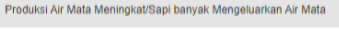 & 3 & Gubah 8 Hapus \\
\hline 18 & cacing & G21 & Berat Badan Menurun dan Kurus & 5 & Gunan x x rapus \\
\hline 19 & Gacing & 620 & Natsu Makan Bertambahn & 1 & Gubain $x$ Hapus \\
\hline 20 & Virus & 011 & Konsistensi Kotoran Cair dan Banyak & 5 & $x$ Utain $x$ Hapus \\
\hline 21 & vous & 910 & Then Genestaran & 3 & Guan xhens \\
\hline 22 & vons & 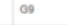 & Kult Kuram & 3 & Guom x rom \\
\hline 23 & vous & a & Mengobam Keobuan & s & Guam Xhous \\
\hline 24 & vous & G7 & Kobsoesk Mes Bermena Meran & 5 & room xhooum \\
\hline 25 & van & ob & Demam & 1 & 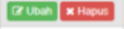 \\
\hline 26 & vons & as & 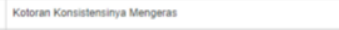 & 3 & row xhom \\
\hline${ }^{27}$ & mas & os & Lomes Dan Mvan Jatan & 3 & ruan xhem \\
\hline 28 & vons & as & Kull Terouvos: & 5 & 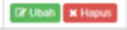 \\
\hline 20 & mon & ${ }^{2} 2$ & 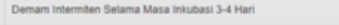 & 5 & 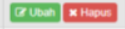 \\
\hline 30 & vas & o1 & Nabsu Matan Menunan & , & 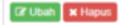 \\
\hline
\end{tabular}

Gambar 1. Daftar Gejala

Gambar 1. Tampilan pada sistem yang menunjukkan daftar gejala disertai dengan bobot tingkat kepercayaan. Daftar gejala di-input berdasarkan gejala yang dialami oleh sapi untuk mendapatkan hasil diagnosa.

\begin{tabular}{|c|c|c|c|}
\hline \multicolumn{4}{|c|}{ Daftar Solusi/Tindakan } \\
\hline \multicolumn{3}{|c|}{ Tampilkan $10 \quad$ baris } & Pencarian: \\
\hline & Ko & - Nama Solusi & + Tambah \\
\hline 1 & To & Lakukan karantina terhadapternak yang sakkit & [C Ubah $\times$ Hapus \\
\hline 2 & $\mathrm{TO} \mathrm{z}$ & Pengoobatan SIMTOMA (pemberran viramIn penambar natsu makan) & [C Uban $\times$ Hapus \\
\hline 3 & $\mathrm{~T} 03$ & Pemberian antibioitkuntuk mencegah inieksi sekunder & [C Ubah $\times$ Hapus \\
\hline 4 & Tos & Disuntik analgesik,anti preteti(obat penurun panas) & CUbah $\times$ Hapus \\
\hline 5 & Tos & Pemberian anti biotik dan vitamin & C Ubah $\times$ Hapus \\
\hline 6 & Tod & Pemberian antibioik gram negatf ftau spectrum luas & Co ubah $\times$ Hapus \\
\hline 7 & Tor & Pemberian vitamin dan obat anti diare & CUbah $\times$ Hapus \\
\hline 8 & Tos & Pemberian anti bloattimpani & C Ubah $\times$ Hapus \\
\hline 9 & Tos & Mengeluarkan kotoran dengan palpasi rekal & Co ubah $\times$ Hapus \\
\hline 10 & $T_{10}$ & Trocar (RetDole) & C Ubah $\times$ Hapus \\
\hline 11 & TH1 & anthistamin (anf alerg) & CUbah $\times$ Hapus \\
\hline 12 & $\mathrm{~T} 12$ & Obat cacing secara berkala & Q Ubah $\mathbf{x}$ Hapus \\
\hline 13 & $\mathrm{~T} 13$ & Jangan mengetuarikan sapi terilulu pagi & Qubah $\times$ Hapus \\
\hline 14 & T14 & Meniaga kebersishan kandangysanntasi kantang & Q Qubah $\times$ Hapus \\
\hline 15 & T15 & Pemberian vitamin & Q U Ubah $\times$ Hapus \\
\hline 16 & $\mathrm{~T} 16$ & Pemberian obat tht (intermetitim) & CUbah X Hapus \\
\hline 17 & T17 & Menjaga kebershan temak Imemanolkan temak seminggu sekal & CUbah X Hapus \\
\hline
\end{tabular}

Gambar 2. Daftar Solusi Pencegahan 
Gambar 2. Tampilan pada sistem yang menunjukkan daftar solusi pencegahan yang harus dilakukan oleh para peternak untuk melakukan penanganan dini terhadap gejala penyakit yang diderita oleh sapi. Daftar solusi pencegahan berdasarkan gejala-gejala yang diderita oleh sapi.

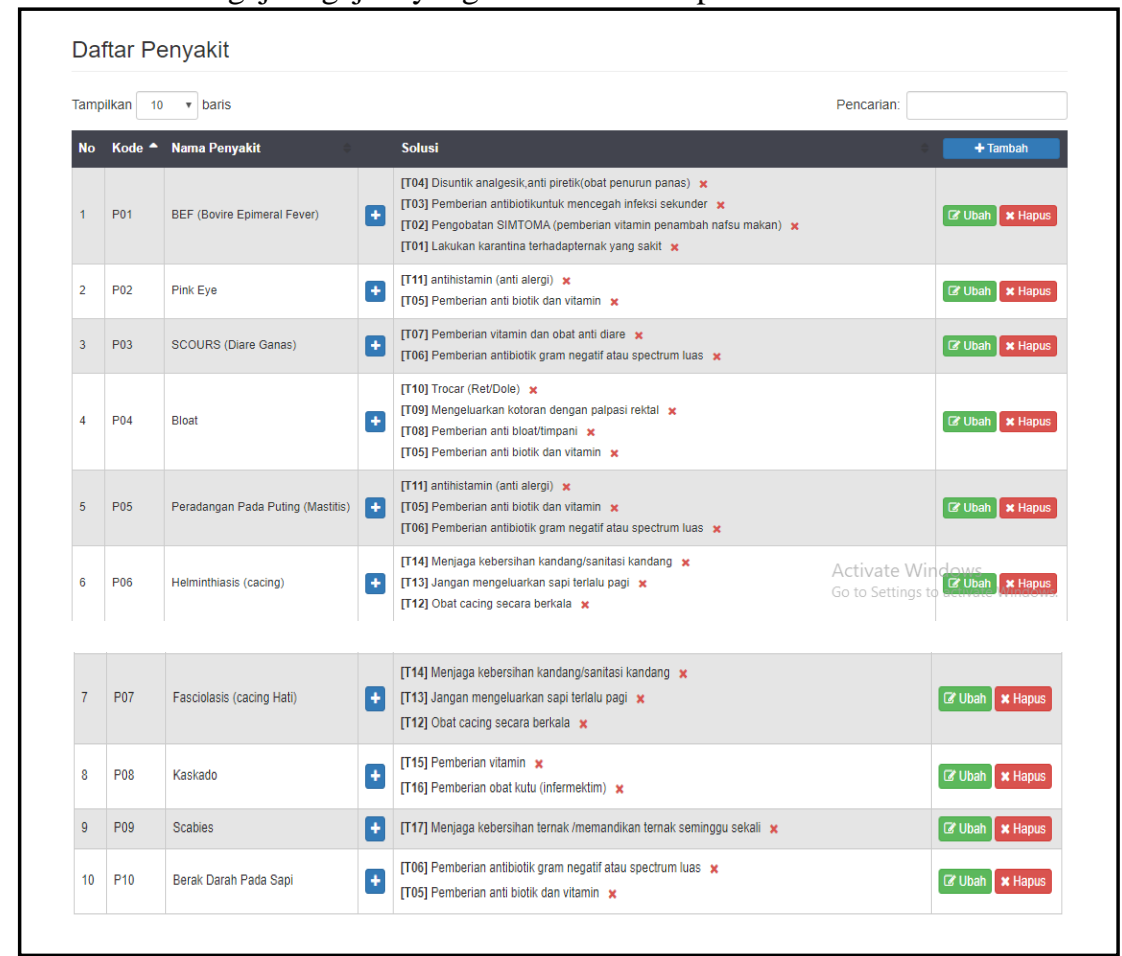

Gambar 3. Basis Pengetahuan

Gambar 3 merupakan tampilan pada sistem yang menunjukkan tampilan basis pengetahuan solusi penanganan terhadap penyakit. Dengan adanya basis pengetahuan para peternak bisa mengetahui solusi dan tindakan yang harus dilakukan oleh para peternak ketika menghadapi ternak mereka yang mengalami sakit.

\section{Pengujian Sistem}

Dalam tahapan pengujian sistem, penelitian ini menggunakan model pengujian whitebox yaitu sebuah metode pengujian yang mengutamakan fungsi input dan output sistem apakah sudah sesuai dengan yang diharapkan atau belum, setiap fungsi di uji secara rinci alur-alur logika sistem sesuai dengan alur sistem pada Gambar 4. Data yang di masukkan dalam sistem adalah data yang diperoleh dari pakar serta berdasarkan faktafakta yang terjadi dilapangan yang sering dikeluhkan oleh para peternak.

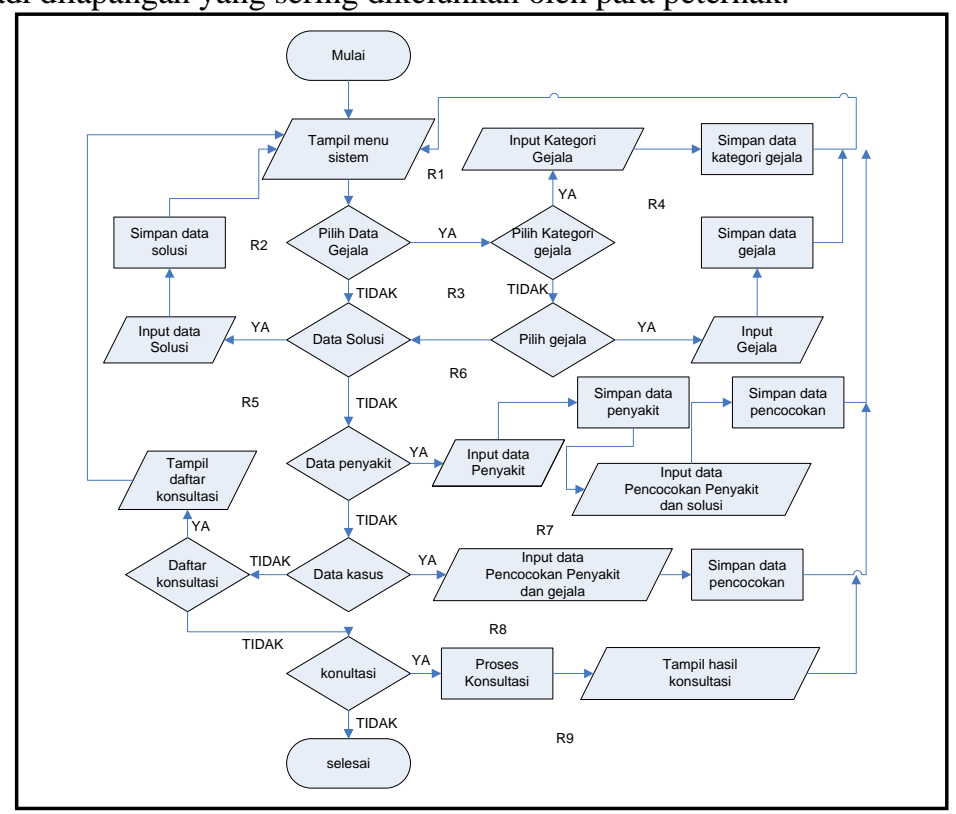

Gambar 4. Flowchart alur sistem 
D. Penerapan Metode Case Based Reasoning

Adapun langkah-langkah perhitungam metode Case Based Reasoning berdasarkan proses pada sistem yang telah dibuat adalah sebagai berikut:

1. Proses Retrieve

Pengguna menginput gejala-gejala yang dialami pada awal proses kemudian menekan tombol lanjutkan untuk mengetahui hasil diagnosa. Selanjutnya sistem melakukan proses pembobotan dengan melakukan pencocokan satu persatu terhadap gejala yang ada dalam basis pengetahuan. Proses melakukan pembobotan dengan perhitungan:

Bobot Parameter (w): Tingkat Kasus Penyakit:

Gejala Penting $=5 \quad$ Ringan $=0-0.25$

Gejala Sedang $=3 \quad$ Akut $=0.26-0.50$

Gejala Biasa $=1 \quad$ Kronis $=0.51-0.75$

Kritis $=0.76-1$

Tabel 3, Tabel 4 dan Tabel 5, menunjukkan nilai dari setiap variable perhitungan untuk Kasus BEF, Pink Eye, dan Scours.

Tabel 3. Perhitungan [P01] BEF (Bovire Epimeral Faver)

\begin{tabular}{|c|c|c|}
\hline Kasus Baru & & Kasus Lama \\
\hline [G1] Nafsu Makan Menurun & 1 & [G1] Nafsu Makan Menurun \\
\hline $\begin{array}{l}\text { [G2] Demam Intemiten selama } \\
\text { Masa Inkubasi 3-4 Hari }\end{array}$ & 5 & $\begin{array}{l}\text { [G2] Demam Intemiten selama Masa } \\
\text { Inkubasi 3-4 Hari }\end{array}$ \\
\hline [G3] Kulit Terkelupas & 5 & [G3] Kulit Terkelupas \\
\hline [G4] Lemas Dan Mudah Jatuh & 3 & [G4] Lemas Dan Mudah Jatuh \\
\hline [G13] Lambung Penuh Gas & & [G5] Kotoran Konsistensinya Mengeras \\
\hline
\end{tabular}

Tabel 4. Perhitungan [P02] Pink eye

\begin{tabular}{lll}
\hline \multicolumn{1}{c}{ Kasus Baru } & & \multicolumn{1}{c}{ Kasus Lama } \\
\hline [G6] Demam & 1 & {$[\mathrm{G} 6]$ Demam } \\
\hline $\begin{array}{l}\text { [G7] Kelopak Mata Berwarna } \\
\text { Merah }\end{array}$ & 5 & {$[\mathrm{G} 7]$ Kelopak Mata Berwarna Merah } \\
\hline [G8] Mengalami Kebutaan & 5 & [G8] Mengalami Kebutaan \\
\hline [G9] Kulit Kusam & & \\
\hline [G10] Tubuh Gemetaran & & \\
\hline
\end{tabular}

$$
\text { Similarity }(X, P E)=\frac{(1 * 1)+(1 * 5)+(1 * 5)}{1+5+5}=\frac{11}{11}=1
$$

Tabel 5. Perhitungan [P03] SCOURS (Diare Ganas)

\begin{tabular}{ll}
\multicolumn{1}{c}{ Kasus Baru } & \multicolumn{1}{c}{ Kasus Lama } \\
\hline [G1] Nafsu Makan Menurun & [G1] Nafsu Makan Menurun \\
\hline [G2] Demam Intemiten selama & [G9] Kulit Kusam \\
Masa Inkubasi 3-4 Hari & \\
\hline [G3] Kulit Terkelupas & [G10] Tubuh Gemetaran \\
\hline [G4] Lemas Dan Mudah Jatuh & [G11] Konsistensi Kotoran Cair Dan \\
\hline [G13] Lambung Penuh Gas & Banyak \\
\hline
\end{tabular}

$$
\text { Similarity }\left(X_{s} S C\right)=\frac{101}{1+3+2+5}=\frac{1}{11}=0.09
$$

Persamaan (1), (2), dan (3) yaitu perhitungan proses retrieve berdasarkan bobot gejala yang muncul, jika gejala kasus baru sama dengan gejala kasus lama maka $1 \mathrm{x}$ bobot parameter sebaliknya jika gejala kasus baru berbeda dengan gejala kasus lama maka $0 \mathrm{x}$ bobot parameter.

\section{Proses Reuse}

Berdasarkan perhitungan diatas kasus SC yang memiliki bobot paling rendah yaitu 0,09 sedangkan bobot yang paling tinggi dimiliki oleh kasus PE yaitu 1. Dalam proses ini memberikan solusi dengan kemiripan kasus bobot dari kasus lama dengan kasus baru yang lebih tinggi. Pada kasus PE memiliki bobot lebih tinggi dan positif terkena penyakit pink eye, solusi yang diberikan adalah pemberian anti alergi serta pemberian anti biotik dan vitamin. 


\section{Proses Revise}

Proses Revise yaitu proses peninjauan kembali kasus dan solusi yang diberikan pada proses retrieve sistem tidak bisa memberikan hasil diagnosa yang tepat. Dalam kasus diatas penyakit pink eye telah menghasilkan solusi dan solusi yang dihasilkan tersebut bisa langsung diberikan. Namun jika ternyata setelah proses perhitungan tidak ditemukan kasus yang mirip dengan kasus baru maka dilakukan proses revise.

\section{Proses Retain}

Setelah proses revise selesai dan sudah mendapatkan solusi yang benar-benar tepat barulah pakar menambah aturan dan memasukan data kasus baru yang sudah didapatkan solusinya kedalam basis pengetahuan yang nantinya dapat digunakan untuk kasus berikutnya yang memiliki permasalahan yang sama Proses inilah yang dinamakan retrain.

\section{Kesimpulan dan saran}

Berdasarkan hasil yang diperoleh, terlihat bahwa kasus SC memiliki bobot paling rendah yaitu 0,09 dan tertinggi pada kasus PE yaitu 1, dapat ditarik kesimpulan bahwa penerapan metode CBR baik digunakan untuk sistem pakar diagnosa penyakit ternak sapi. Sistem ini sangat membantu para peternak dalam mendiagnosa penyakit sapi. Para peternak lebih cepat mendapatkan informasi tentang penyakit yang diderita sapi tanpa harus betemu langsung dengan pakar terutama para peternak yang lokasinya sangat jauh dari pakar. Dengan adanya sistem pakar ini para peternak sapi lebih menghemat waktu untuk mendiagnosa penyakit yang di derita oleh sapi sehingga para peternak bisa langsung memberikan penanganan awal pada ternak sapi mereka.

\section{Ucapan Terima Kasih}

Terimakasih kepada DRPM Ristekdikti, LLDikti Wilayah IX dan Lembaga Penelitian Universitas Ichsan Gorontalo yang telah memberi kesempatan dalam Penelitian Dosen Pemula.

\section{Daftar Pustaka}

[1] Z. Mantau, Warda, D. Walangadi, F. S. I. Hiola, and Rosdiana, "Kajian Kebijakan Agribisnis Komoditas Unggulan Daerah di Provinsi Gorontalo," 2012.

[2] P. Ternak and K. Pohuwato, "Sumber : Dinas Peternakan dan Kesehatan Hewan Kabupaten Pohuwato," 2015.

[3] R. Adawiyah, S. Informasi, U. Sembilanbelas, and N. Kolaka, "Case Based Reasoning Untuk Diagnosis Penyakit Demam Berdarah,” vol. 1, no. 1, pp. 63-73, 2017.

[4] R. Rika, "Sistem Pakar Konsep dan Teori." p. 121, 2012.

[5] Anonim. 2007. Case-Based Reasoning: Foundational Issues, Methodological Variations, and SystemApproaches. Artificial Intelligence Communications. IOS Press, Vol 7: 1 .

[6] S Montani, LC Jain, Successful Case-Based Reasoning Applications-2.2, Berlin: Springer, 2010

[7] BPS Kabupaten Pohuwato, “ Peternakan”, Kabupaten Pohuwato Dalam Angka 2019. 75030.1901. Pohuwato : BPS Kabupaten Pohuwato, 2019, Agriculture, Peternakan, 158

[8] S. Mulyana, S. Hartati, R. Wardoyo, and E. Winarko, "Case-Based Reasoning for Selecting Study Program in Senior High School," Int. J. Adv. Comput. Sci. Appl., vol. 6, no. 4, pp. 136-140, 2015, doi: 10.14569/ijacsa.2015.060418.

[9] Direktorat Kesehatan Hewan, Manual Penyakit Hewan Mamalia. Cetakan Ke 2. Jakarta : Subdit Pengamatan Penyakit Hewan Direktorat Kesehatan Hewan, 2014

[10] S. Nidhra, "Black Box and White Box Testing Techniques - A Literature Review," Int. J. Embed. Syst. Appl., vol. 2, no. 2, pp. 29-50, 2012, doi: 10.5121/ijesa.2012.2204.

[11] A. S. Rosa, M. Shalahudin, Rekayasa Perangkat Lunak (Terstruktur dan Berorientasi Objek). 2011. Bandung: Modula. 2011

[12] S. Sibagariang, "Sistem Pakar Diagnosa Penyakit Sapi Dengan Metode," vol. IV, no. 2, pp. 35-39, 2015.

[13] R. Dwi Oktavianing Tyas and A. Andy Soebroto, "Pengembangan Sistem Pakar Diagnosa Penyakit Sapi Potong Dengan Metode Fuzzy K-Nearest Neighbour,” J. Enviromental Eng. Sustain. Technol., vol. 2, no. 1, pp. 58-66, 2015, doi: 10.21776/ub.jeest.2015.002.01.8.

[14] I. Candra Dewi, A. Andy Soebroto, and M. Tanzil Furqon, "Sistem Pakar Diagnosa Penyakit Sapi Potong Dengan Metode Naive Bayes," J. Enviromental Eng. Sustain. Technol., vol. 2, no. 2, pp. 72-78, 2015, doi: 10.21776/ub.jeest.2015.002.02.2.

[15] A. Milzam, N. Hidayat, and M. C. Mahfud, "Sistem Pakar Diagnosis Penyakit Pada Sapi Menggunakan Metode Dempster-Shafer Berbasis Android,” vol. 2, no. 10, pp. 3767-3770, 2018. 